\title{
Proposals for the Future of Internal Crowdsourcing: A Trade Union-Based Approach
}

\author{
Welf Schröter
}

\begin{abstract}
The "FST" personnel network "Forum Soziale Technikgestaltung" (Forum for Social Forms of Technology) from the German Trade Union Confederation (DGB) of Baden-Württemberg has been examining the subjects informatization of work and digitization since 1991. More than 4600 women and men from works councils and staff councils, union representative bodies and the workforce, large companies, small- and medium-sized enterprises, the manual trades, as well as self-employed people have been involved in an exchange about their experiences in production and services and in administrations. Against this background, and drawing on the accumulated knowledge gained from experience, the following proposals for the future of internal crowdsourcing have been derived. The proposals represent a trade union-based approach.
\end{abstract}

Keywords Order-related innovation · External crowdsourcing · Open external crowdsourcing $\cdot$ Platform-related crowdwork

\section{Proposals for the Future of Internal Crowdsourcing}

\subsection{Proposal 1}

Platform-based crowdsourcing has seen continued pluralization and increased differentiation. Thanks to the new process flows emerging from the digital transformation, we will see crowdsourcing merge increasingly with crowdworking. This means that a specific crowdsourcing that is methodologically conceived in the narrower sense will become the exception in the everyday working scenario.

\footnotetext{
W. Schröter $(\bowtie)$

Forum Soziale Technikgestaltung beim DGB, Baden-Württemberg, Mössingen, Germany

e-mail: schroeter@talheimer.de
} 


\subsection{Proposal 2}

Platform-based crowdworking is establishing itself increasingly in the area of industrial production, industry-related services, the private services sector, the civil service, the manual trades, and the financial sector.

\subsection{Proposal 3}

As virtual transaction spaces and platforms that were previously stand-alone grow together over time, new potentials of crowdsourcing unfold as part of modern crowdworking. Thinking and working in an order-related manner as well as a move away from focusing on purely vertical toward mainly horizontal valuecreation chains in future, together with models of partially autonomous and agile working, will lead to a dominant culture of crowdsourcing applications. The boundaries between internal and external crowdsourcing are becoming blurred, and both dynamics are merging with one another. Due to the progressive removal of boundaries in company operations, the division between internal and external utilizations will slowly fade.

\subsection{Proposal 4}

The pluralization of user cultures is bringing forth different variants and models:

1. Internal crowdsourcing as voluntary internal innovation management

2. Internal crowdsourcing as order-related innovation

3. Internal, order-related crowdsourcing linked to selective external crowdsourcing

4. Internal crowdsourcing with permanently open external crowdsourcing

5. Flexible agile models of order-related crowdsourcing

6. Differing platform-related crowdwork

Evidence shows that the variants mentioned in nos. 2-6 will ultimately cover around two-thirds to three-quarters of the coming platform-based working environments.

\subsection{Proposal 5}

Among the big challenges facing us in the near future is the question of whether and how well the transitions between the variants named in nos. 1-6 will succeed from the point of view of the workforce. The interfaces between the variants present 
greater challenges than the inherent implementation within them. Working people will be forced to constantly change back and forth between these models. If the organizational models are not intelligent enough, not flexible enough, and not compatible, the result will be obstacles, time delays, errors, and failures. What is needed is an intelligent, inclusive self-management to handle these changes.

\subsection{Proposal 6}

Following on from Proposal 5, the question arises as to whether qualification strategies should concentrate more on the interfaces and on being able to manage these or more on the inherent processes within the respective variants.

\subsection{Proposal 7}

From current experiences with "self-learning" software applications and with "autonomous software systems," it can be concluded that the variants named in Proposal 4 (nos. 2-6) will be augmented and partly controlled by "self-learning" and "autonomous" systems (software) in the near future (Schröter 2019). This would underscore the relevance of order-related processes for value creation.

\section{Reference}

Schröter W (2019) Der mitbestimmte Algorithmus. Arbeitsweltliche Kriterien zur sozialen Gestaltung von Algorithmen und algorithmischen Entscheidungssystemen. In: Schröter W (ed) Der mitbestimmte Algorithmus. Gestaltungskompetenz für den Wandel der Arbeit. Talheimer Sammlung kritisches Wissen, vol 85. Talheimer, Mössingen, pp 101-150

Welf Schröter is the head of the personnel network "Forum Soziale Technikgestaltung" (in German "FST") at DGB Baden-Württemberg and acts as a partner in the Federal Ministry of Education and Research project "Internes Crowdsourcing in Unternehmen: Arbeitnehmergerechte Prozessinnovationen durch digitale Beteiligung von Mitarbeiter/innen" (Internal Crowdsourcing in Companies: Employee-Friendly Process Innovations Through the Digital Participation of Employees; in German "ICU”). 
Open Access This chapter is licensed under the terms of the Creative Commons Attribution 4.0 International License (http://creativecommons.org/licenses/by/4.0/), which permits use, sharing, adaptation, distribution and reproduction in any medium or format, as long as you give appropriate credit to the original author(s) and the source, provide a link to the Creative Commons licence and indicate if changes were made.

The images or other third party material in this chapter are included in the chapter's Creative Commons licence, unless indicated otherwise in a credit line to the material. If material is not included in the chapter's Creative Commons licence and your intended use is not permitted by statutory regulation or exceeds the permitted use, you will need to obtain permission directly from the copyright holder. 